\title{
RADIOCARBON DATING OF PREHISTORIC SHELL FROM NEW ZEALAND AND CALCULATION OF THE $\triangle R$ VALUE USING FISH OTOLITHS
}

\author{
T. F. G. HIGHAM and A. G. HOGG
}

Radiocarbon Dating Laboratory, School of Science and Technology, University of Waikato
Hamilton, New Zealand

\begin{abstract}
We calculated a new $\triangle R$ for New Zealand waters using ${ }^{14} \mathrm{C}$ dates of historic shell previously presented by McFadgen and Manning (1990), and fish otoliths dated by Kalish (1993). We obtained a new estimate of $-25 \pm 15{ }^{14} \mathrm{C}$ yr. To test the accuracy of this value for correcting conventional ${ }^{14} \mathrm{C}$ marine ages, we dated shell of a variety of different species excavated at the prehistoric site of Shag Mouth, North Otago. We compared the results with a pooled mean date for terrestrial samples and calculated a local $\Delta R$ value that we found statistically indistinguishable from the new $\Delta R$ estimate for New Zealand.
\end{abstract}

\section{INTRODUCTION}

The brevity of human occupation in New Zealand ( $<1 \mathrm{ka})$ has demanded that radiocarbon dating specialists and archaeologists alike minimize all uncertainties associated with sample type. Many scholars, for example, have identified uncertainties caused by the "inbuilt age" (McFadgen 1982) of wood that causes charcoal dates to be too old (Trotter 1968, Caughley 1988, Anderson 1991). This may be the result of growth age, in which the age of dead wood in the center of the living tree is dated, or of storage age, which refers to the amount of time elapsed from the death of the tree to its use by people (McFadgen 1982). Anderson (1991) and Anderson, Smith and Higham (ms.) suggested spurious collagen dates may have been caused by pretreatment methods that lacked reproducibility and by the use of fossil bone in prehistory.

Uncertainties have also been identified in dates of certain species of shell. Uncertainties may be introduced by dissolved bicarbonate of infinite age from calcareous rock formations near estuaries around the New Zealand coast. A number of important prehistoric sites are estuarine and old carbon is thought to have affected ${ }^{14} \mathrm{C}$ dates of shell collected in them (Anderson 1991). There is also the problem of upwelling. Anderson (1991) has suggested that this effect may explain old shell dates from Avoca Point on the Kaikoura Peninsula because it borders on an important upwelling zone. Physiological factors also affect the reproducibility of dating some shell species. Measurements on Amphibola crenata (mudsnail), for instance, have frequently given spurious results. This may be because it is a deposit-feeding, rather than filter-feeding organism, and the age of organic muds it subsists upon may artificially affect its ${ }^{14} \mathrm{C}$ activity (Higham 1993).

Shell offers three important advantages for the prehistorian: 1) it usually dates an archaeological event closely. Shellfish are seldom transported long distances; most are collected and processed in the same vicinity (Meehan 1982); 2) shell remains are ubiquitous in New Zealand archaeological contexts; 3 ) the marine calibration curve is smoother for shell than for terrestrial samples. One of the major problems in ${ }^{14} \mathrm{C}$ dating New Zealand prehistory has been obtaining a sufficient level of precision to answer specific archaeological questions. With dates on shell, there are fewer multiple intercepts and the calibrated ranges derived are narrower than for samples formed in equilibrium with atmospheric carbon (Stuiver and Braziunas 1993).

We focus here upon the accuracy of correcting for the reservoir effect. We analyze the New Zealand $\Delta \mathrm{R}$ value and recalculate it using additional historic material. We then test it at one major New Zealand prehistoric site using shell-charcoal pairs. 


\section{RECALCULATION OF THE NEW ZEALAND $\triangle$ R VALUE}

The apparent age of oceanic water is caused both by the delay in exchange rates between atmospheric $\mathrm{CO}_{2}$ and ocean bicarbonate, and the dilution effect caused by the mixing of surface waters with upwelled deep waters (Mangerud 1972). A reservoir correction must be made to any shell dates to account for this difference. Shell dates in New Zealand were once corrected using the New Zealand Marine Shell Standard (Rafter et al. 1972). This was based upon the depletion measured in a sample of shellfish, Austrovenus stutchburyi (common cockle), collected live from Pounawea, South Otago in 1955. The net depletion in $\Delta^{14} \mathrm{C}$ was measured at $-40 \% 0$ (Rafter et al. 1972). This equated to a reservoir correction of $330{ }^{14} \mathrm{C}$ yr. Later measurements suggested the offset was $-41 \%$, so a constant $336{ }^{14} \mathrm{C}$ yr was subtracted from all shell conventional ages (Jansen 1984).

Conventional shell dates may now be corrected using the modeled marine calibration curve developed by Stuiver, Pearson and Braziunas (1986), which reflects secular variations in ${ }^{14} \mathrm{C}$ production in the atmosphere. A local reservoir correction $(\Delta R)$ can be applied to account for regional oceanic differences. The New Zealand $\Delta \mathrm{R}$ value originally given by Stuiver, Pearson and Braziunas (1986) was $-65 \pm 25^{14} \mathrm{C}$ yr. McFadgen and Manning (1990) recalculated this to $-30 \pm 13{ }^{14} \mathrm{C}$ yr using 11 measurements on historic shell. The samples were different species that came from open marine beaches, a river mouth and an estuary (Table 1). The measured activities were statistically indistinguishable and were pooled using the method described by Ward and Wilson (1978) (error-weighted mean method). In addition to correcting a conventional shell date with a constant factor, then, the marine calibration model, with $\Delta \mathrm{R}$ set at $-30 \pm 13{ }^{14} \mathrm{C}$ yr, also accounts for secular variation in ${ }^{14} \mathrm{C}$ production. $\Delta \mathrm{R}$ itself is assumed to be time-independent.

TABLE 1. $\Delta \mathrm{R}$ Calculation for New Zealand

\begin{tabular}{llcccccr}
\hline & Sample & $\begin{array}{c}\text { Birth } \\
\text { Lab no. }\end{array}$ & $\begin{array}{c}\text { Date } \\
\text { sun }\end{array}$ & \multicolumn{1}{c}{$\Delta^{14} \mathrm{C}$} & $\begin{array}{l}\text { Conv. }{ }^{14} \mathrm{C} \\
\text { age (BP) } \dagger\end{array}$ & $\begin{array}{l}\text { (Q) } \\
\text { age } \ddagger\end{array}$ & \multicolumn{1}{c}{$\Delta \mathrm{R}$} \\
\hline NZA-2740 & Otolith (P. auratus) & 1918 & 1992 & $-48.4 \pm 6.4$ & $429 \pm 57$ & 464 & $-35 \pm 57$ \\
NZ-1799 & Dosinia anus & 1923 & 1973 & $-52.0 \pm 6.0$ & $410 \pm 46$ & 465 & $-55 \pm 46$ \\
NZ-1814 & P. subtriangulatum & 1925 & 1973 & $-65.0 \pm 7.0$ & $515 \pm 56$ & 466 & $49 \pm 56$ \\
NZA-2799 & Otolith (P. auratus) & 1928 & 1992 & $-39.6 \pm 6.9$ & $345 \pm 61$ & 467 & $-122 \pm 61$ \\
NZA-2741 & Otolith (P. auratus) & 1932 & 1992 & $-58.5 \pm 6.4$ & $501 \pm 58$ & 469 & $32 \pm 58$ \\
NZA-2721 & Otolith (P. auratus) & 1943 & 1992 & $-51.1 \pm 6.6$ & $427 \pm 59$ & 477 & $-50 \pm 59$ \\
NZA-2797 & Otolith (P. auratus) & 1943 & 1992 & $-55.0 \pm 7.2$ & $461 \pm 65$ & 477 & $-16 \pm 65$ \\
NZ-1813 & A. stutchburyi & 1949 & 1973 & $-55.0 \pm 6.0$ & $432 \pm 46$ & 482 & $-50 \pm 46$ \\
NZA-2742 & Otolith (P. auratus) & 1950 & 1992 & $-65.9 \pm 6.2$ & $546 \pm 57$ & 483 & $63 \pm 57$ \\
NZ-114 & P. ventricosum & 1953 & 1957 & $-62.0 \pm 5.0$ & $506 \pm 39$ & 484 & $22 \pm 39$ \\
NZ-1481 & P. subtriangulatum & 1954 & 1972 & $-62.0 \pm 4.0$ & $494 \pm 35$ & 485 & $9 \pm 35$ \\
NZ-4698 & Alcithoe arabica & 1954 & 1979 & $-58.0 \pm 4.0$ & $451 \pm 32$ & 485 & $-34 \pm 32$ \\
NZ-2421 & Haliotis sp. & 1954 & 1955 & $-52.0 \pm 8.0$ & $422 \pm 62$ & 485 & $-63 \pm 62$ \\
NZ-2433 & Cellana sp. & 1954 & 1955 & $-57.0 \pm 8.0$ & $464 \pm 62$ & 485 & $-21 \pm 62$ \\
NZ-2431 & A. stutchburyi & 1954 & 1955 & $-48.0 \pm 6.0$ & $390 \pm 44$ & 485 & $-95 \pm 44$ \\
\hline
\end{tabular}

*Paphies ventricosum $=$ the toheroa; Dosinia anus $=$ a cockle-like bivalve; Alcithoe arabica $=$ a gastropod of the Volutidae family; Cellana sp. = limpets; Protothaca crassicostata = a type of cockle; Paphies subtriangulatum = the tuatua.

†All shell dates and $\Delta^{14} \mathrm{C}$ values are taken from McFadgen (1978) and McFadgen and Manning (1990). Otolith data are from Kalish (1993) and conventional ${ }^{14} \mathrm{C}$ ages and $\Delta^{14} \mathrm{C}$ values are courtesy of $\mathrm{R}$. Sparks (Institute of Geological and Nuclear Sciences, Ltd). The error-weighted mean value for $\Delta R=-25.8 \pm 11.1{ }^{14} \mathrm{C}$ yr.

$\ddagger Q$ ages refer to the marine model-calculated conventional ${ }^{14} \mathrm{C}$ age of the historical samples (Stuiver, Pearson and Braziunas 1986:982). Post-1950 Q ages are calculated by a linear interpolation of the pre-1950 data (Stuiver and Braziunas 1993). 
We obtained seven more values to augment the New Zealand $\Delta R$ data from Kalish's (1993) measurements of New Zealand snapper otoliths (Pagrus auratus) of known age from the east coast of the North Island (Table 1). They were collected from an area with no significant upwelling. Kalish (1993) was able to use the results to trace the pre- and post-bomb ${ }^{14} \mathrm{C}$ signal in southern temperate ocean waters. We used these data for reservoir correction because the species are restricted to shallow, inshore waters. Otoliths were aged and aragonite from the year when the fish were spawned was sampled and dated by accelerator mass spectrometry (AMS) (Kalish 1993). We used Stuiver and Braziunas' (1993) marine calibration curve to calculate $\Delta R$ for both this set of results and McFadgen and Manning's (1990) set (Table 1). The Kalish (1993) data set for pre-1950 results is statistically indistinguishable from McFadgen and Manning's (1990) data. We extrapolated the postAD 1500 surface graph $\left({ }^{14} \mathrm{C}\right.$ yr vs. cal yr) (Stuiver and Braziunas 1993: Fig. 14) beyond 1950 by linear interpolation to calculate all of the $\Delta R$ values. The value we obtain for $\Delta R$ using the errorweighted mean is $-25.8 \pm 11.1{ }^{14} \mathrm{C}$ yr $\left(\mathrm{T}^{\prime}=15.86 ; \chi^{2}{ }_{17: 0.05}=27.59\right)$ (Table 1). We obtain an unweighted mean and "scatter" sigma uncertainty of $-27.6 \pm 10.7$. We rounded up the $\Delta R$ sigma to $\pm 15{ }^{14} \mathrm{C}$ yr after Stuiver and Braziunas (1993), so the $\Delta \mathrm{R}$ value becomes $-25.8 \pm 15^{14} \mathrm{C} \mathrm{yr}$.

\section{$\triangle$ R AT SHAG MOUTH, NORTH OTAGO}

We analyzed charcoal-shell pairs from Shag Mouth, a site in North Otago (Fig. 1), to test the applicability of the $\Delta \mathrm{R}$ value to an archaeological situation. Other scholars measured reservoir corrections in Australasia using the paired charcoal-shell method (Law 1984 (in New Zealand); Gillespie and Temple 1977; Gillespie and Polach 1979; Head, Jones and Allen 1983 (in Australia)). In these comparisons, it must be assumed that stratigraphically identical materials were deposited simultaneously. Law (1984) compared archaeological shell (corrected using the New Zealand Marine Shell Standard) and charcoal pairs and found that, on average, charcoal dates were older by $83{ }^{14} \mathrm{C} \mathrm{yr}$. $\mathrm{He}$ attributed this to the inbuilt age in the charcoal samples. The mode, or most common value of his data, however, was $+25^{14} \mathrm{C}$ yr in favor of shell (i.e., shell was older by $25{ }^{14} \mathrm{C} \mathrm{yr}$ ). Gillespie and Polach (1979) dated shells of known historical age from Australian coastal waters and calculated a reservoir correction of $450 \pm 35{ }^{14} \mathrm{C}$ yr. They analyzed shell-charcoal pairs excavated from prehistoric aboriginal middens to test the result, and found age differences ranging from -25 to $775^{14} \mathrm{C}$ yr (Gillespie and Polach 1979). They concluded that the discrepancies were due to a combination of inbuilt age and displacement of sample and event, leading to non-systematic age differences between pairs. Head, Jones and Allen (1983) reached similar conclusions.

Little (1993) examined $\Delta R$ at sites on the eastern U.S. seaboard using a similar method. She concluded that the $\Delta R$ values given by Stuiver, Pearson and Braziunas (1986) accurately corrected shell dates from the region. She found errors in certain results, which she attributed to the influx of carbon of variable age introduced by upwelling, rivers, terrestrial runoff and dissolved bicarbonate, which affected the measurable $\Delta R$. Although, in some cases, she used material of known historical age, the inbuilt age of many charcoal and wood samples she used for her analysis may have accounted for some of the discrepancies she observed. Two criteria must be satisfied in measuring reservoir corrections and $\Delta R$ using paired prehistoric charcoal and shell dates: 1 ) the material must be in identical stratigraphic association; 2) all wood and charcoal samples must be identified and only wood from short-lived species, seeds or twigs, selected for dating. Even under these circumstances, some uncertainty will remain. Any analysis of $\Delta \mathrm{R}$ should take this into account. Thus, we suggest that, for calibration purposes, the uncertainty term given with a $\Delta R$ value measured using this method should be increased routinely. In his analysis of $\Delta R$ in the Hawaiian Islands, Dye (1994) reached similar conclusions. The conclusions of Law (1984) and Little (1993) might have been different had they examined their raw ${ }^{14} \mathrm{C}$ data and sample provenience critically prior to analysis. M. Schmidt (University 


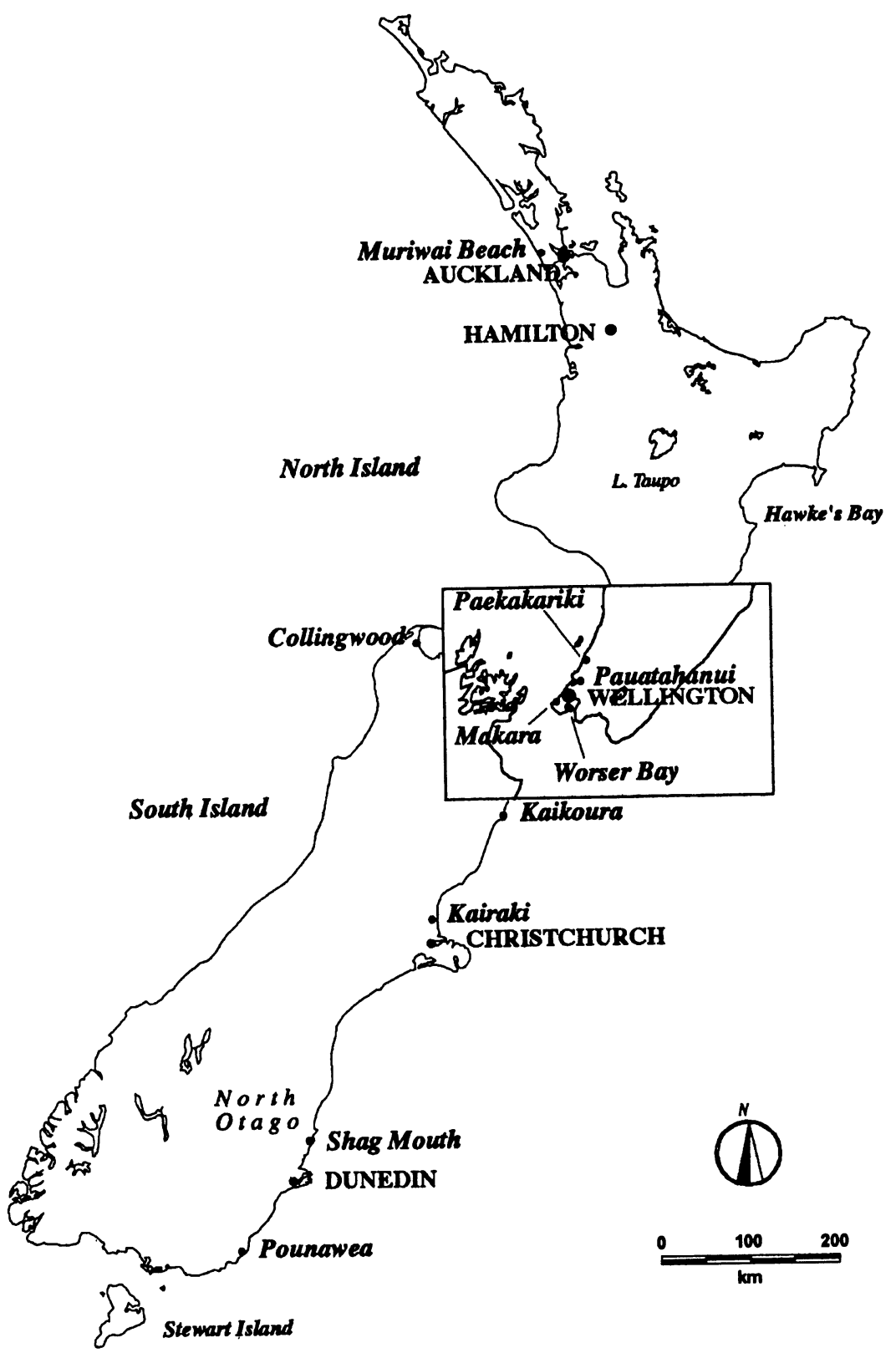

Fig. 1. Map of New Zealand showing sites mentioned in the text, including all sites where shell and otoliths used in the $\Delta R$ calculation were obtained

of Waikato, personal communication 1994), for example, evaluated all archaeological shell-charcoal pairs measured in the Institute of Geological and Nuclear Sciences (IGNS), ${ }_{1}^{1}$ Lower Hutt, New Zealand, and found that only five of $c a .40$ pairs are robust enough for comparison when rigorous discard protocols, as outlined by Anderson (1991) and Spriggs and Anderson (1993), are applied.

${ }^{1}$ From B. G. McFadgen's (Department of Conservation, Wellington) New Zealand archaeological database 
Anderson (1991) developed a ${ }^{14} \mathrm{C}$ discard protocol to determine the likeliest date for the colonization of New Zealand. He rejected several ${ }^{14} \mathrm{C}$ assays, including dates adrift by $\geq 300{ }^{14} \mathrm{C}$ yr from those in a series otherwise within $1 \sigma$ of one another and dates of charcoal that were not identified and that may have contained inbuilt age.

The Shag Mouth site is important in prehistoric investigations in southern New Zealand because of its large size (over $2 \mathrm{ha}$ ), deep stratigraphy (over $2 \mathrm{~m}$ deep in parts) and the range of artifacts recovered. It is one of few sites in the region thought once to have been a permanently occupied village (Skinner 1924). The site has been studied intensively, beginning with von Haast (1874). Material used in this analysis comes from the 1988 excavations (Anderson, Smith and Allingham, ms.) during which 10 $\mathrm{m}^{2}$ was excavated atop the highest part of the dune (Fig. 2). The remains of butchered moa dominate the lower areas; the upper strata consist mainly of shellfish and fish.

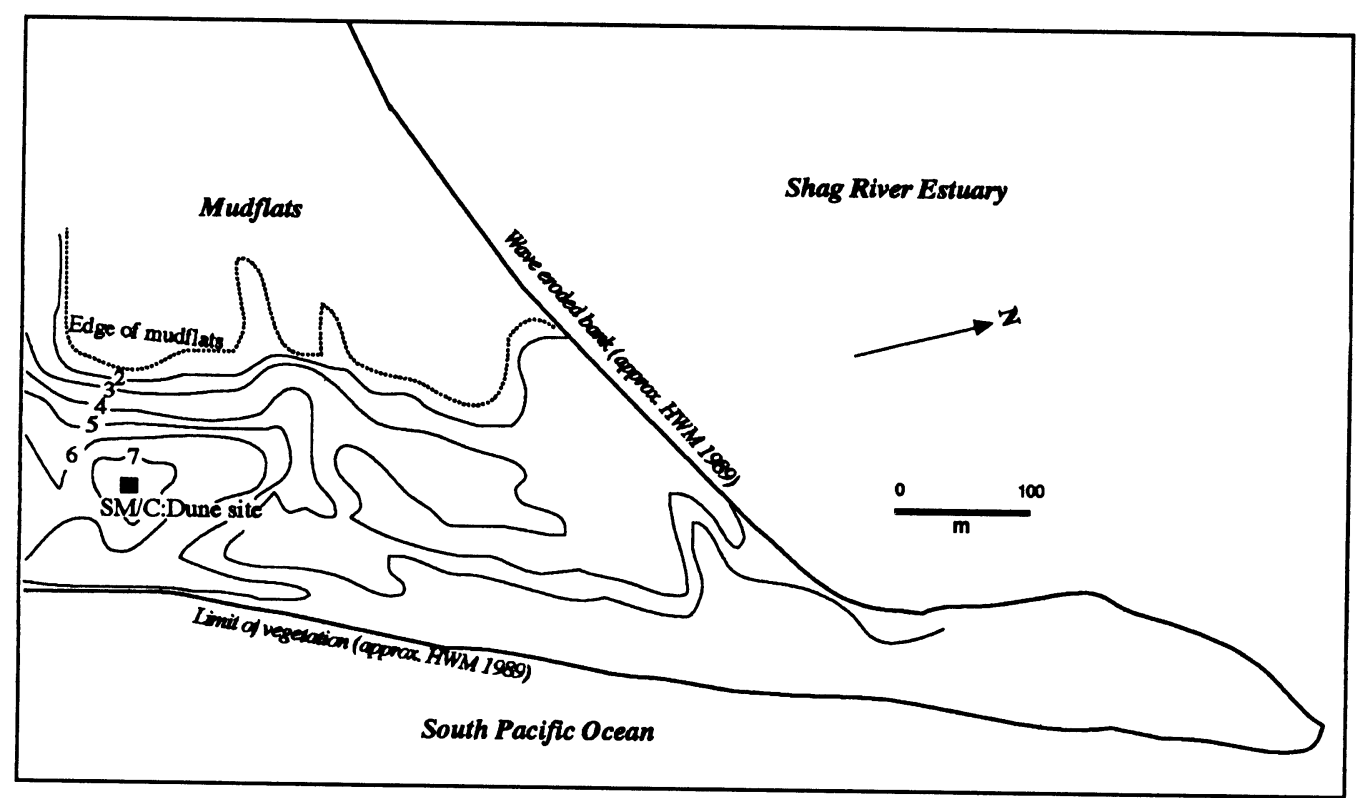

Fig. 2. The site of Shag Mouth, North Otago, New Zealand, located on a sand dune separating the sea from the Shag River estuary. The samples used in this paper came from the 1988 excavations at the SM/C dune site. Contour lines represent
meters above sea level.

We chose the site for $\Delta R$ analysis for a variety of reasons: 1 ) more ${ }^{14} \mathrm{C}$ dates are available here than for any other site in New Zealand; thus, there are immediate data for comparison. Further, the ${ }^{14} \mathrm{C}$ record suggests a short period of prehistoric occupation (see below). This has been confirmed archaeologically; there is no evidence for any significant hiatus among any of the 11 discrete layers in this part of the site (Anderson, Smith and Allingham, ms.); 2) all wood and charcoal samples were identified, and only short-lived and twig remains were selected for dating. Dates from these samples have been cross-checked for accuracy using moa eggshell and bone (see Anderson, Smith and Higham, ms., and Higham 1993, 1994 for details). This ensures that the terrestrial samples date the prehistoric event as closely as possible, and are cross-checked for validity; 3 ) there is a variety and abundance of shell remains for dating. Thus, it has been possible to check on the ${ }^{14} \mathrm{C}$ content of different species and the presence, or absence, of a hard-water effect in the environment of the Shag River estuary. Analysis of the prehistoric dates and an investigation into dating modern individual 
shellfish from this site and others outside the region suggests that there is no measurable hard-water effect here (Higham 1993); 4) pretreatment experiments on both charcoal and shell remains from several layers of the site have led us to conclude that there is little significant post-depositional contamination that could provide spurious dating results (Higham 1993).

There are 13 identified charcoal dates and 19 shell dates from the site (Anderson, Smith and Higham, ms.). The charcoal dates are indistinguishable statistically from one another at the 0.95 probability level. The error-weighted mean value for charcoal is $620 \pm 13 \mathrm{BP}\left(\mathrm{T}^{\prime}=5.31 ; \chi^{2}{ }_{12: 0.05}=\right.$ 21.03). Of the 19 shell dates, we rejected 5 from the $\Delta R$ analysis (Table 2). NZ-7804 was a date of Haliotis iris, which was very young compared to two others of the same species and dates from the same stratigraphic layer. Anderson, Smith and Higham (ms.) concluded from the XRD analyses of the shell carbonate that it may have been partially recrystallized. We also rejected two dates of Amphibola crenata (the mudsnail) because of its proven unreliability (Higham 1993; see above) and two dates of Austrovenus stutchburyi used in an unrelated experiment.

TABLE 2. Shell Dates from the Site of Shag Mouth, New Zealand

\begin{tabular}{cllrr} 
LabLE 2. Shell Dates from the & Site of & $\begin{array}{l}\text { Provenience } \\
\text { (square, layer) }\end{array}$ & $\begin{array}{r}\text { Conventional } \\
{ }^{14} \text { C age (BP) }\end{array}$ & ${ }^{13} \mathrm{C}$ \\
\hline-- & Charcoal A'(p) $\ddagger$ & -- & $620 \pm 13$ & n.a. \\
Wk-2362 & A. stutchburyi & G8, L4 & $1010 \pm 50$ & +1.3 \\
Wk-2364 & A. stutchburyi & G8, L4 spit 7 & $1040 \pm 50$ & +1.3 \\
Wk-2410 & A. stutchburyi & F7 L4 & $1020 \pm 50$ & +1.5 \\
Wk-2411 & A. stutchburyi & F7 L4 & $990 \pm 45$ & +0.8 \\
Wk-2412 & A. stutchburyi & F7 L4 & $980 \pm 45$ & +1.2 \\
Wk-2508 & A. stutchburyi & G8, L4 spit 7 & $1060 \pm 45$ & -0.2 \\
Wk-2632 & P. australis & J5 L4 & $980 \pm 40$ & +1.4 \\
Wk-2751 & A. stutchburyi & F7 L4 & $960 \pm 45$ & +1.0 \\
Wk-2752 & M. edulis aoteanus & J5 L4 & $1040 \pm 45$ & +1.0 \\
Wk-2856 & A. stutchburyi & J5 L4 & $980 \pm 40$ & +1.0 \\
Wk-2857 & A. stutchburyi & J5 L4 & $950 \pm 45$ & +1.0 \\
NZ-7805 & H. iris & H8 L4 & $965 \pm 26$ & +0.7 \\
NZ-7806 & H. iris & A2 L7 & $1022 \pm 29$ & +1.0 \\
NZA-1175 & H. iris & C-D/7-8, L11 & $974 \pm 49$ & +0.7 \\
\hline
\end{tabular}

"Wk = Radiocarbon Dating Laboratory, University of Waikato; NZ = Institute of Geological and Nuclear Sciences, Lower Hutt; NZA = AMS dates from the IGNS. NZ shell dates are courtesy of Prof. A. J. Anderson (Australian National University, Canberra) and Dr. I. W. G. Smith (University of Otago, Dunedin).

$\dagger$ Austrovenus stutchburyi $=$ the common cockle; Paphies australis = the pipi; Mytilus edulis aoteanus $=$ the New Zealand subspecies of the widely found mussel family; Haliotis iris = the paua (abalone). All are bivalves with the exception of the paua.

$\ddagger$ Charcoal $\mathrm{A}^{\prime} p=620 \pm 13 \mathrm{BP}\left(\mathrm{T}^{\prime}=5.31 \chi_{12: 0.05}^{2}=21.03\right)$.

Instead of comparing single shell-charcoal pairs directly, the mean of shell dates was measured against the mean of the charcoal series to improve $\Delta R$ precision. We used the surface ocean ${ }^{14} \mathrm{C} /$ atmospheric ${ }^{14} \mathrm{C}$ figures of Stuiver and Braziunas (1993: 154) to convert the terrestrial mean to a model marine age $\mathrm{BP}$, after deducting $40{ }^{14} \mathrm{C} \mathrm{yr}$ for the southern hemisphere terrestrial correction (Vogel et al. 1993). We obtained $980 \pm 13 \mathrm{BP}$ as a model marine age. This measurement was deducted from the mean of the conventional shell dates to give $\Delta R$, the local reservoir correction (Stuiver and Braziunas 1993). We obtained a mean shell date of $995 \pm 11 \mathrm{BP}$. This yields a $\Delta R$ of 15 $\pm 17^{14} \mathrm{C}$ yr for Shag Mouth. We calculated the $\Delta \mathrm{R} \sigma$ using $\sqrt{ } \sigma$ marine $^{2}+\sigma$ terrestrial $^{2}$ (Stuiver, Pear- 
son and Braziunas 1986). We measured the reservoir difference $(R(t))$ between the mean conventional shell age $\left(\mathrm{P}_{\mathrm{ma}}\right)$ and the pooled mean terrestrial age $\left(\mathrm{P}_{\mathrm{at}}\right)$ using $\mathrm{P}_{\mathrm{ma}}-\mathrm{P}_{\mathrm{at}}$ (Table 2) (Little 1993). The $R(t)$ value was $375 \pm 17 \mathrm{BP}$. The pooled $\Delta \mathrm{R}$ measurement of $13 \pm 17^{14} \mathrm{C}$ yr for the Shag Mouth shell series is statistically indistinguishable from our New Zealand $\Delta R$ estimate of $-25.8 \pm 15^{14} \mathrm{C} \mathrm{yr}$. However, it is distinguishable from the McFadgen and Manning (1990) $\Delta R$. The most likely explanation for this discrepancy, we suggest, involves the data used to generate the two calibration models. The 1993 marine curve differs by approximately two decades for the past cal $7 \mathrm{ka}$ from the original 1986 version. According to Stuiver and Braziunas (1993) this is due to a change in the inputs calculated for the model ocean in the earlier parts of the curve, which are now based on the data derived from Barbadian corals (Bard et al. 1990; 1993). No modifications were made to the original $\Delta R$ values (Stuiver, Pearson and Braziunas 1986: Fig. 10B), because the corrections would have been approximately equal to most of the original rounded-off amounts.

We also compared the calibrated charcoal mean with the calibrated shell mean using the revised $\Delta R$ estimate of $-25 \pm 15{ }^{14} \mathrm{C}$ yr. At $1 \sigma$, the shell mean data was cal AD 1338-1385 and at $2 \sigma$, cal AD 1323-1401 (Stuiver and Braziunas 1993). The charcoal mean gave cal AD 1294-1317 (.57 probability) and 1370-1386 (.43) at $1 \sigma$ and cal $\mathrm{AD} 1289-1326(.53), 1351-1362(.08)$ and 1366-1390 (.39) at $2 \sigma$ (Stuiver and Becker 1993). The closeness of the fit suggests that the revised $\Delta R$ value produces calibrated data in agreement with terrestrial materials.

\section{Conclusion}

Our results suggest that the new $\Delta R$ estimate would correct shell dates accurately from the site within statistical limits, and shows that the regional ocean exhibited some stability over the very recent past. The analysis of the $\Delta \mathrm{R}$ value for Shag Mouth also provides more compelling evidence that to ${ }^{14} \mathrm{C}$ date reservoir corrections accurately and precisely using sample pairs, the nature and environment of the material to be dated must be carefully scrutinized. Charcoal material must be identified and only short-lived material selected. Post-depositional contamination and the influence of environmental effects within the site orbit, such as the hard-water effect, must be investigated. A discard protocol should be applied to reject ${ }^{14} \mathrm{C}$ measurements that may be affected by these factors. As more information on local reservoir conditions is obtained, the value for New Zealand's $\Delta R$ may continue to change. Thus, the onus shall again be upon the user of the ${ }^{14} \mathrm{C}$ data to publish all information regarding the type of calibration curve used and the value for $\Delta R$. Until there are further refinements to the accuracy of calibrating shell dates, the Waikato laboratory will use the revised New Zealand $\Delta R$ estimate for all shell reservoir corrections.

\section{ACKNOWLEDGMENTS}

This research was supported by a grant from the Royal Society of New Zealand Skinner Fund for Prehistory and a University of Waikato Vice-Chancellor's Scholarship. We thank Professor A. J. Anderson (Australian National University, Canberra) and Dr. I. W. G. Smith (University of Otago, Dunedin) for providing some of the ${ }^{14} \mathrm{C}$ dates from the Shag Mouth site. We are grateful to Dr. B. F. Leach (National Museum of New Zealand, Wellington) and Mr. M. Schmidt (Radiocarbon Dating Laboratory, University of Waikato, Hamilton) for their input. Dr. R. Sparks (IGNS, Lower Hutt) kindly provided the otolith conventional ${ }^{14} \mathrm{C}$ ages.

\section{REFERENCES}

Anderson, A. J. 1991 The chronology of colonization in New Zealand. Antiquity 65(249): 767-795.

Anderson, A. J., Smith, I. W. G. and Allingham, B. J.,

eds., (ms.). Shag Mouth: The Archaeology of an Early Southern Maori Village. New Zealand Archaeological Association Monograph. In preparation. 
Anderson, A. J., Smith, I. W. G. and Higham, T. F. G. (ms.) Radiocarbon chronology. In Anderson, A. J., Smith, I. W. G. and Allingham, B. J., eds., Shag Mouth: The Archaeology of an Early Southern Maori Village. New Zealand Archaeological Association Monograph. In preparation.

Bard, E., Arnold, M., Fairbanks, R. G. and Hamelin, B. $1993{ }^{230} \mathrm{Th}-{ }^{234} \mathrm{U}$ and ${ }^{14} \mathrm{C}$ ages obtained by mass spectrometry on corals. In Stuiver, M., Long, A. and Kra, R. S., eds., Calibration 1993. Radiocarbon 35(1): 191-199.

Bard, E., Hamelin, B., Fairbanks, R. G. and Zindler, A. 1990 Calibration of the ${ }^{14} \mathrm{C}$ timescale over the past 30000 years using mass spectrometric U-Th ages from Barbados corals. Nature 345: 405-409.

Caughley, G. 1988 The colonisation of New Zealand by the Polynesians. Journal of the Royal Society of New Zealand 18: 245-70.

Dye, T. 1994 Apparent ages of marine shells: Implications for archaeological dating in Hawai'i. Radiocarbon 35(2): 51-57.

Gillespie, R. and Polach, H. A. 1979 The suitability of marine shells for radiocarbon dating of Australian prehistory. In Berger, R. and Suess, H. E., eds. Radiocarbon Dating. Proceedings of the 9th International Conference on Radiocarbon Dating. Berkeley/Los Angeles, University of California Press: 404-421.

Gillespie, R. and Temple, R. B. 1977 Radiocarbon dating of shell middens. Archaeology and Physical Anthropology in Oceania 12(1): 26-37.

Gupta, S. K. and Polach, H. A. 1985 Radiocarbon Dating Practices at ANU. Handbook, Radiocarbon Dating Laboratory, Research School of Pacific Studies, ANU, Canberra.

Head, M. J, Jones, R. and Allen, J. 1983 Calculation of the "Marine Reservoir Effect" from the dating of shell-charcoal paired samples from an aboriginal midden on Great Glennie Island, Bass Strait. Australian Archaeology 17: 99-112.

Higham, T. F. G. (ms.) 1993 Radiocarbon Dating the Prehistory of New Zealand. Ph.D. dissertation, University of Waikato, New Zealand: $236 \mathrm{p}$.

1994 Radiocarbon dating New Zealand prehistory with moa eggshell: Some preliminary results. Quaternary Geochronology (Quaternary Science Reviews) 13: 163-169.

Jansen, H. S. 1984 Institute of Nuclear Sciences INS-R328 Radiocarbon Dating for Contributors. Institute of Nuclear Sciences, DSIR, Lower Hutt: 56 p.

Kalish, J. M. 1993 Pre- and post-bomb radiocarbon in fish otoliths. Earth and Planetary Science Letters 114(4): 549-554.

Law, R. G. (ms.) 1984 Archaeological carbon dating using shell - the New Zealand experience. Paper presented at the New Zealand Archaeological Association Conference, Oamaru, June 1984.

Little, E. A. 1993 Radiocarbon age calibration at archaeological sites of coastal Massachusetts and vicinity. Journal of Archaeological Science 20: 457-471.
Mangerud, J. 1972 Radiocarbon dating of marine shells, including a discussion of apparent ages of Recent shells from Norway. Boreas 1: 143-172.

McFadgen, B. G. 1978 Radiocarbon in modern marine shells compared with the New Zealand standard. New Zealand Journal of Science 21: 311-313.

1982 Dating New Zealand archaeology by radiocarbon. New Zealand Journal of Science 25: 379-92.

McFadgen, B. G. and Manning, M. 1990 Calibrating New Zealand radiocarbon dates of marine shells. $R a$ diocarbon 32(2): 229-232.

Meehan, B. 1982 Shell Bed to Shell Midden. Atlantic Highlands, New Jersey, Humanities Press: 189 p.

Rafter, T. A., Jansen, H. S., Lockerbie, L. and Trotter, M. M. 1972 New Zealand radiocarbon reference standards. In Rafter, T. A. and Grant-Taylor, T., eds., Proceedings of the 8th International Conference on Radiocarbon Dating. Wellington, New Zealand, The Royal Society of New Zealand: 625-675.

Skinner, H. D. 1924 Results of the excavations at the Shag River sandhills. Journal of the Polynesian Society 33: 11-25.

Spriggs, M. and Anderson, A. J. 1993. Late colonisation of East Polynesia. Antiquity 67: 200-17.

Stuiver, M., Pearson, G. W. and Braziunas, T. F. 1986 Radiocarbon age calibration of marine samples back to 9000 cal yr BP. In Stuiver, M. and Kra, R. S., eds., Proceedings of the 12 th International ${ }^{14} \mathrm{C}$ Conference. $R a$ diocarbon 28(2B): 980-1021.

Stuiver, M. and Becker, B. 1993 High-precision decadal calibration of the radiocarbon time scale, AD 19506000 BC. In Stuiver, M., Long, A. and Kra, R. S., eds., Calibration 1993. Radiocarbon 35(1): 35-65.

Stuiver, M. and Braziunas, T. F. 1993 Modeling atmospheric ${ }^{14} \mathrm{C}$ influences and ${ }^{14} \mathrm{C}$ ages of marine samples to 10000 BC. In Stuiver, M., Long, A. and Kra, R. S., eds., Calibration 1993. Radiocarbon 35(1): 137-191.

Stuiver, M. and Polach, H. A. 1977 Discussion: Reporting of ${ }^{14} \mathrm{C}$ data. Radiocarbon 19(3): 355-363.

Stuiver, M. and Reimer, P. J. 1993 Extended ${ }^{14} \mathrm{C}$ data base and revised CALIB $3.0{ }^{14} \mathrm{C}$ age calibration program. In Stuiver, M., Long, A. and Kra, R. S., eds., Calibration 1993. Radiocarbon 35(1): 215-231.

Trotter, M. M. 1968 On the reliability of charcoal for radiocarbon dating New Zealand archaeological sites. New Zealand Archaeological Association Newsletter 11: 86-88.

Vogel, J. C., Fuls, A. M, Visser, E. and Becker, B. 1993 Pretoria calibration curve for short-lived samples, 1930-3350 B.C. In Stuiver, M., Long, A. and Kra, R. S., eds., Calibration 1993. Radiocarbon 35(1): 73-85.

Von Haast, J. 1874 Notes on the Moa-hunter encampment at Shag Point, Otago. Transactions of the New Zealand Institute 7: 91-98.

Ward, G. K. and Wilson, S. R. 1978 Procedures for comparing and combining radiocarbon age determinations: a critique. Archaeometry 20(1): 19-31. 